\title{
La comunicación y su relación con las metamorfosis sociales
}

[Editorial]

J. Ignacio 'Iñaki' Chaves G.

Citar como:

Chaves, J. I. (2021). La comunicación y su relación con las metamorfosis sociales. Análisis, 53(98). https://doi.org/10.15332/21459169.6459

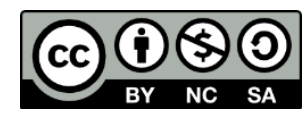

La comunicación en el año de la COVID-19 ha sufrido una metamorfosis inesperada. La falta o reducción del contacto directo, físico, en comunidad, la ha transformado, al punto de afectar sobremanera a las relaciones sociales que se han visto metamorfoseadas en su esencia. Las formas comunicativas de la puesta en común han cambiado y se han visto trasladadas a la virtualidad.

Las pantallas han cobrado más relevancia si cabe en el proceso comunicativo que ha perdido uno de sus pilares, el compartir en vivo y en directo. Las plataformas han visto aumentado su uso y ese reporte semanal de nuestros dispositivos móviles, "su tiempo en pantalla ha sido de $x$ horas y $x$ minutos”, ha crecido exponencialmente. Hemos vivido el año 2020 pegados a las redes virtuales, en un confinamiento cuyo impacto ha sido tal que ha hecho, incluso, que la Fundéu la haya elegido palabra del año. Por otro lado, se ha acentuado la diferencia entre dos mundos: el real y el virtual, en los que la comunicación se ha roto en el primero porque no

\footnotetext{
* Doctor en Comunicación y Ciencias Sociales. Editor invitado.
} 
existe el compartir, porque las pantallas conectan, pero no unen. No sabemos si estamos solos frente al computador o si hay alguien al otro lado. Solamente un círculo o un logo señalan que alguien está conectado, pero no que estemos realmente comunicados con quienes están al otro lado. ¿Hay cuerpos más allá? Nos hemos convertido en medios, en lienzos de un museo comunicacional virtual que se nos representa como la realidad, una realidad a la que no estábamos acostumbrados.

Este número quería ser una especie de ajiaco de Bogotá (cual sopa de Wuhan $^{1}$ ) con viandas de producción nacional e internacional que recogiera una parte del sentir académico bogotano, colombiano y latinoamericano en general sobre lo que se estaba pensando durante la pandemia, sobre la pandemia y por efecto de esta. Queríamos conocer de apuestas, reflexiones e investigaciones sobre la comunicación que, desde las diferentes prácticas pedagógicas, sociológicas, artísticas, políticas o periodísticas, abordaran el futuro posible, o imposible, que se nos viene en un mundo que ya no será el que era y en el que habrá mucho que cambiar para no perder, o recuperar, el camino de la verdadera comunicación con base en el humanismo, la ética y los valores.

Relatos "envueltos" por coronavirus o "revueltos" por el virus. Porque narrar nos ayuda a sanar y sanarNOS, para salir de esta locura, que nos dicen que es más loca que las anteriores, pero que es una muestra más de la enajenación mental de nuestra especie. Reflexiones tal vez no tan académicas, sino más bien sentidas, más del corazón que de la cabeza, cercanas a lo sentipensante.

Escribir y reflexionar sobre una situación desconocida e impensable en la que hemos presenciado cómo el miedo ha ganado la partida a la libertad,

${ }^{1}$ Sopa de Wuhan, compendio de escritos de pensamiento contemporáneo publicados en el primer trimestre de 2020 en Buenos Aires por la editorial Aislamiento Social Preventivo y Obligatorio. 
cómo la dictadura del encierro ha superado a la democracia de las reuniones, cómo las pantallas y sus "me gusta" o sus "compartir" se han apoderado del lugar de los verdaderos abrazos, cómo la muerte "natural", por ser causada por una enfermedad, ha opacado otras muertes, las de la violencia estructural.

Contar y narrar sueños e inquietudes provocadas por la pandemia. Soñar para seguir existiendo en este mar de incertidumbres al que nos ha llevado a navegar el coronavirus sin dejarnos aprovisionar para la ocasión. El SARS-CoV-2 nos ha empujado de bruces sobre la incertidumbre, muy distinta de la del principio de Heisenberg, $\mathrm{y}$ ha hecho añicos las seguridades de la anterior realidad. Ahora vivimos dizque en la "nueva normalidad", como si lo de antes fuera normal, si es que eso existe. Estamos siendo, sin quererlo, protagonistas de la película de moda, esa que se ha ganado "todas las portadas de los medios y que se ha estrenado, con apenas unos días de margen, en las salas de casi todo el planeta con gran asistencia de público" (Chaves, 2020). Y sigue aumentando cada día. Todavía no sabemos en qué parte del recorrido estamos.

No podemos escapar a los pensamientos de incredulidad y de sospecha que nos hacen sentir que todo pueda ser una cortina de humo que, bajo el manto de un virus que lo llena todo, oculta lo que sigue sucediendo entre bastidores, las otras realidades que golpean a la gente y al planeta, y que seguirán haciéndolo cuando la pandemia se acabe, cosa que anhelamos. Pero mientras se aclara, o no, el panorama, es bueno recapacitar y narrar lo pensado durante el confinamiento en este plato académico tan peculiar en el que podrán leer sobre la pandemia y sobre otros temas relevantes, aunque tal vez no estén de tanta actualidad. Así, se encontrarán con: Un artículo sobre la agenda noticiosa creada por las redes virtuales alrededor de la violencia en la vecina Venezuela en 2017 y su repercusión 
en dos medios tradicionales en sus versiones digitales que reflejaron, según la autora, una información sensacionalista, comercial e irrespetuosa. Con un acercamiento a la educación pública en Bogotá durante la pandemia, en la que docentes y orientadoras han tenido que recurrir a otras estrategias, críticas y transformadoras, para enriquecer su labor en el paso obligado de la presencialidad a la virtualidad.

Un análisis de la cobertura mediática de The New York Times a algunos de los tiroteos que sucedieron en escuelas de los Estados Unidos y cómo el medio cambió su estilo narrativo haciendo uso de un papel más crítico al elevar el marco del conflicto sobre el del interés humano.

Una especulación acerca de la comunicación y el contacto en estos tiempos pandémicos e inciertos, que estamos viviendo como si fuera una mala película de ciencia ficción, a partir de un recorrido virtual por una pinacoteca ad hoc con obras que sirven como metáfora de lo que estamos viviendo. El poder para la construcción de la realidad que atesoran las imágenes es la base para preguntarse si estamos en un cambio de paradigma sobre el rol de estas en la sociedad, haciendo una reflexión sobre sus narrativas de la vida y del mundo y su interpretación en la elaboración de la memoria, todo ello partiendo del reconocimiento de la fuerza comunicativa de las imágenes.

La necesaria construcción de paz se puede abordar desde muchos ámbitos, entre ellos cabe también el de la enseñanza del idioma inglés. El artículo "An other rading of peace" lo hace partiendo de las conexiones entre lenguaje y conflicto, a través de "un campo de incertidumbres metodológicas y una caja de herramientas creativa" que pone en cuestión algunos discursos subyacentes.

Una mirada al proceso de inclusión de estudiantes afrodescendientes en la Universidad Santo Tomás en Bogotá concluye que, pese a no existir 
prácticas ni documentos que la promuevan explícitamente, sí se está abriendo la posibilidad de construirla en diferentes instancias. Para ello, se ha partido de la revisión de los documentos institucionales y del respaldo de los testimonios personales recogidos en unas entrevistas, de las que salieron categorías como discriminación, identidad e inclusión. Se concluyó que se requieren acuerdos sobre el término 'afrodescendiente' y estrategias institucionales para la inclusión.

Los resultados de una tesis doctoral sobre la concepción de la ciencia desde la diversidad cultural del profesorado de ciencias naturales y educación ambiental en Colombia se presentan en un artículo que expone las percepciones presentes y su relación con la enseñanza. Describe el cuerpo metodológico para analizar el objeto de investigación y finalmente encuentra la epistemología universalista como el eje sobresaliente en la formación profesoral en ciencias.

Las desigualdades sociales de las mujeres, más allá de su género, se abordan en un texto teórico reflexivo en el que se constata que es la educación uno de los epicentros de esta problemática en Colombia, rastreando una brecha en términos de colonización e interseccionalidad que se sigue reproduciendo permanentemente. Para ello se observan los desafíos que tiene la educación superior.

Un acercamiento a la Ética de Spinoza es lo que presenta un trabajo que sigue la senda del filósofo racionalista neerlandés, donde se abordan las concepciones antropológicas, ontológicas y éticas del perseguido autor para concluir que 'libertad' y 'necesidad' son conceptos plenamente compatibles.

Para intentar esclarecer el posible nexo existente entre conocimiento y práctica humana, en "Intelectualismo ético en Platón" se describen los 
postulados éticos y gnoseológicos de Platón en un artículo que aborda el libro VII de la República.

Y para terminar, un artículo que quiere llegar a proponer un acontecer del pensamiento que ensanche la lógica de este y que abra la posibilidad de coinstitucionalizar un pensamiento cívico que los autores consideran tan necesario en los tiempos que vivimos.

En estos momentos inciertos en los que la humanidad se ha visto sacudida por otro de los virus, con los que convivimos desde siempre, este número 98 de la revista Análisis se presenta tan heterogéneo como interesante. Una sopa intelectual y autóctona atravesada por la comunicación y por esas metamorfosis sociales sufridas en el mundo, para lo bueno y para lo malo, durante la pandemia en la que todavía nos encontramos y que nos debería llevar a reflexionar sobre esas frases de Hilel el Sabio que cita Bernard-Henri Lévy (2020): "Si no me ocupo de mí, ¿̇quién lo hará?”, pero "Si solamente me ocupo de mí, entonces ¿̇qué soy?"

\section{Referencias}

Chaves, J. I. (2020, junio 14). El encierro como una película. Pateras al Sur. https://paterasalsur.wordpress.com/2020/06/14/el-encierro-como-una-pelicula/

Fundación del Español Urgente. (2020, 29 de diciembre). Confinamiento, palabra del año 2020 para la FundéuRAE. Fundéu. https://www.fundeu.es/recomendacion/confinamiento-palabra-del-ano-2020para-la-fundeurae/

Lévy, B. H. (2020). Este virus que nos vuelve locos. La esfera de los libros. 